\title{
High-volume surgeons and high-volume journals in a multivariate orthopedic environment
}

\author{
Marius M. Scarlat ${ }^{1,2} \cdot$ Marko Pećina ${ }^{2,3} \cdot$ Andrew Quaile ${ }^{2,4}$ \\ Published online: 31 July 2018 \\ (C) SICOT aisbl 2018
}

Since comparison and ranking exists in health care patients are looking for the best options based on the availability and specific expertise of the providers. Society learned that specialization is the key for the best care and medical decisions became even more nuanced as the specialties in medicine and surgery evolved to become supra-specialties, surgery divided into many branches and every branch split further still. We are now facing new challenges as specific rare diseases could be referred to the best possible experts and this is extremely important when facing life-threatening conditions, such as cancer or heart disease. Medical information spread over the Internet made more information available for each patient. The patient could eventually improve his or her condition with appropriate hygiene, food, and exercise, and ultimately get in touch with the specialists in the field, conveniently in their own country or region. Orthopedic surgery is important for society as the freedom of motion and an active life can be improved in a majority of cases. The Bone and Joint Decade is a continuous action started in 2000 and engaged hundreds of thousands of health professionals all over the globe serving the ultimate goal that is the well-being of our fellow-patients and SICOT is a part of this continuous effort $[1,2]$.

The information provided over the Internet can be authored by different individuals; some sites could provide irrelevant information in a surgeon's analysis [3]. A recent study points out that very few sites include data issued exclusively by the

Marius M. Scarlat

mscarlat@gmail.com

1 Clinique Chirurgicale St Michel, Toulon, France

2 International Orthopaedics - SICOT Official Journal, Brussels, Belgium

3 Department of Orthopaedic Surgery, School of Medicine University of Zagreb, Zagreb, Croatia

4 FRCS, Spineworks, London, UK surgeons who perform specific procedures, such as for example knee arthroplasty [4].

Volume-outcome relationship seems to be positive for a multitude of procedures [5, 6]. However, the benefits of high-volume work seem to be related more to the doctors performing health care than to the hospital organization or volume. Toomey et al. found a positive association between outcomes of a specific difficult surgical procedure and highvolume surgeons, regardless of the hospital volume. "The benefits of undertaking the procedure at a high-volume hospital are transferred to a low-volume hospital when highvolume surgeons relocate" [7]. The best results follow highvolume surgeons. At a fast glance, we may presume that specialization will also increase success rate for a given procedure and also minimize costs, as the specialized centers will concentrate human and technical resources and provide better quality and service, higher success rates for a lower cost per procedure. A study by Mahmoudi and Coll [8] points out that the concentration of tools and expertise results in similar costs per procedure as compared to low-volume centers performing the same technique - free tissue transfer (FTT) was taken as example. The findings did not show any strong association between the care provider volume and the cost of the procedure. The authors suggest that the surgeon volume or experience might have a positive effect on not only the success of the operation but also on the postoperative care. Providing better postoperative care might lead to a lower rate of complications, and therefore, lower cost. Having a better structure and process in place to avoid potential complications is more common in high- versus low-volume hospitals.

Procedure or implant-related databases and registries could be the solution for understanding outcomes based on the average professional. This is particularly true in procedures that are growing in volume, such as the shoulder arthroplasty [9] and also in the follow-up of new implants or procedures on a local, regional, or national basis $[10,11]$.

Successful therapy is defined by healing or diminished sufferance as measured by specific objective scales and scores, 
life quality improvement, and patient-reported positive outcomes $[12,13]$. Patient satisfaction can be self-assessed and different specific scales and measures are now used worldwide for a variety of joints [14-16]. They can even predict aggravation of complications according to a large series published by colleagues from Sweden, based on the national Hip Arthroplasty Register [17].

However, the exclusive use of patient-reported outcomes (PROMS) could hide severe complications or aggravation with some medications or substance consumption [18] and PROMS used as single evaluation for success can lead to errors. Patients should be seen and evaluated by clinicians, the outcome studies have logic rules based on ethics and on experience. Outcome studies can have errors especially when data is missing or when evaluation scales are not coherent [19].

Progress comes from science, from experience, from truth. This is particularly important in surgery and it is not necessarily the biggest, the richest, the oldest, or the fanciest department that produces the best ideas, innovations, or research. Rules apply for the average but sometimes the new directions and meaningful papers originated in small centers and were subsequently published in small journals. To take only two examples, the reverse shoulder arthroplasty was conceived in Dijon, that is, a regional capital in France, and was first published as research in the Belgian Journal of Orthopaedics [20] after being refused in Paris. The same fate had the concept of the double mobility hip that originated in St Étienne, a small University City from the Lyon region and became accepted worldwide after many years [21].

In our days, online access to medical information make available instantly all the scientific information within a second, a blink, or a mouse click. Therefore, publishing in small journals is now visible. The keywords replaced the alphabetic research in Academic databases and Boolean analysis taught us that answers a question could be obtained by different algorithms. Small journals, small hospitals, and small countries matter. Private practice, as well as academic work is becoming productive in terms of outcome studies. However, this does have a price: Surgeon's work becomes stressful by the augmentation of evaluations, computer work, administrative, and social endeavors that are time-consuming and can deteriorate the surgeon's quality of life up to burnout or diminution of work capacity [22]. The surgeon's personality and leadership style can interfere the results and the risk-adjusted outcomes [23]. Busy surgeons may have a natural tendency to postpone evaluation, recall missing data when necessary from consultation letters when a database should be completed for a retrospective study. Busy surgeons may have also a natural tendency to consider that patients lost to follow-up are doing well since they don't come back. Particular situations are seen in some geographically densely populated areas [24] or in disaster medicine $[25,26]$. High-volume centers could produce low-quality research related to the percentages of the lost to follow-up that could be particularly important.

The recent special issue of "International Orthopaedics" dedicated to Chinese Orthopaedics is a brilliant example of the management of high-volume databases that represent a huge volume of surgical and medical work [27]. Highvolume work is associated with high-volume publications, and the overall trend is a growth in quantity and quality of published research [28]. We had a similar experience with the special issue dedicated to bone necrosis that brought data from different centers and different directions of research for this invalidating condition, and this collection of articles is already highly downloaded and cited [29, 30].

Meaningful research needs a rapid way to get visible and the current way of journal evaluations is based on citations. How could a scientific journal keep quality and high impact in a rapid changing world? Today, when the references and knowledge are read by computers, how could we keep alive the interest of the professional world for our work and results? How could scientists choose between papers bringing all true data from different series, places, populations? The fact is, that with the evolution of the science in virtually every place on the planet you, can download and read the most recent studies. The number of downloads do not match the number of the resultant citations from a given publication [31]. Recent analysis suggests that some important and meaningful studies published in the Cochrane database of systematic research were consistently of higher methodological quality but cited less frequently than those published in high-impact medical journals [32]. So, where are we heading?

Communication with pairs is essential in surgery. Writing, reading, evaluating, and continuous learning are priorities. The evolution of modern medicine, professional or academic promotion, social visibility, and personal satisfaction are powerful engines that motivate surgeons during their entire career. Success in surgery is measured by the volume and the quality of work. Success in a scientific career is measured by new ideas, creativity, and visibility as well as by teaching qualities, and ultimately by the number of references, citations, impact, indexes of popularity, altmetrics. Reading, writing, evaluating patients, and analyzing results improve a surgeon's ability to cope with change, interact with new ideas, face professional stress, prevail in the continuous competition for better standards in health care. This tendency is seen all over the world [33-37], and as an official journal of the biggest multinational and multicultural orthopedic society, International Orthopaedics will continue publishing perfect and imperfect meaningful studies that represent the honest work of our contributors and members worldwide [38]. 
International Orthopaedics had 441,759 downloads in 2017. This total is calculated from downloads from January through December of 2017.

International Orthopaedics received a 2-year impact factor of 2.377 and a 5 -year impact factor of 2.700 , released in the Clarivate Analytics Journal Citation Reports (JCR) based on 2017 data. Based on analysis and scales, International Orthopaedics is ranked as Q1 journal.

\section{References}

1. http://lhcnews.sicot.org/?id_page=617 SICOT e-Newsletter Issue No. 46 - July 2012, Editorial by Marcos Musafir \& Tony Woolf Bone and Joint Decade (BJD) accessed online July 19, 2018

2. http://bjdonline.org/dr-james-waddell-receives-the-order-ofcanada-for-2018/ accessed online July 19, 2018

3. Koller U, Waldstein W, Schatz KD, Windhager R (2016) YouTube provides irrelevant information for the diagnosis and treatment of hip arthritis. Int Orthop 40(10):1995-2002. https://doi.org/10.1007/ s00264-016-3174-7

4. Shemesh SS, Bronson MJ, Moucha CS (2016) Computer-assisted total knee arthroplasty marketing and patient education: an evaluation of quality, content and accuracy of related websites. Int Orthop 40(10):2003-2009. https://doi.org/10.1007/s00264-016-3215-2

5. Morche J, Mathes T, Pieper D (2016) Relationship between surgeon volume and outcomes: a systematic review of systematic reviews. Syst Rev 5(1):204. https://doi.org/10.1186/s13643-016-0376-4

6. Spaliviero M, Eastham JA (2015) Relationship between surgical volume and patient outcomes. Trends in Urology \& Men's Health March/April 2015, accessed online https://onlinelibrary.wiley.com/ doi/pdf/10.1002/tre.443

7. Toomey PG, Teta AF, Patel KD, Ross SB, Rosemurgy AS (2016) High-volume surgeons vs high-volume hospitals: are best outcomes more due to who or where? Am J Surg 211:59-63. https://doi.org/ 10.1016/j.amjsurg.2015.08.021

8. Mahmoudi E, Lu Y, Chang SC, Lin CY, Wang YC, Chang CJ, Cheng MH, Chung KC (2017) Associations of surgeon and hospital volumes with outcome for free tissue transfer by using the National Taiwan Population Health Care Data from 2001 to 2012. Plast Reconstr Surg 140(3):455e-465e. https://doi.org/10.1097/ PRS.0000000000003593

9. Bayona CEA, Somerson JS, Matsen FA 3rd. (2018) The utility of international shoulder joint replacement registries and databases: a comparative analytic review of two hundred and sixty one thousand, four hundred and eighty four cases. Int Orthop 42(2):351358. https://doi.org/10.1007/s00264-017-3649-1

10. Ferreira A, Prudhon JL, Verdier R, Puch JM, Descamps L, Dehri G, Remi M, Caton JH (2017) Contemporary dual-mobility cup regional and private register: methodology and results. Int Orthop 41(3): 439-445. https://doi.org/10.1007/s00264-017-3405-6

11. Leta TH, Lygre SH, Skredderstuen A, Hallan G, Gjertsen JE, Rokne B, Furnes O (2016) Secondary patella resurfacing in painful nonresurfaced total knee arthroplasties: a study of survival and clinical outcome from the Norwegian Arthroplasty Register (1994-2011). Int Orthop 40(4):715-722. https://doi.org/10.1007/s00264-0153017-y

12. Sultan AA, Mohamed N, Samuel LT, Chughtai M, Sodhi N, Krebs VE, Stearns KL, Molloy RM, Mont MA (2018) Classification systems of hip osteonecrosis: an updated review. Int Orthop. https:// doi.org/10.1007/s00264-018-4018-4
13. Wenger D, Petersson K, Rogmark C (2018) Patient-related outcomes after proximal tibial fractures. Int Orthop. https://doi.org/ 10.1007/s00264-018-3920-0

14. Haragus H, Prejbeanu R, Poenaru DV, Deleanu B, Timar B, Vermesan D (2018) Cross-cultural adaptation and validation of a patient-reported hip outcome score. Int Orthop 42(5):1001-1006. https://doi.org/10.1007/s00264-017-3742-5

15. Han SB, Lee JH, Kim SG, Cui CG, Suh DW, Lee SY, Jang KM (2018) Patient-reported outcomes correlate with functional scores after opening-wedge high tibial osteotomy: a clinical study. Int Orthop 42(5):1067-1074. https://doi.org/10.1007/s00264-0173614-z

16. Hsu JE, Hulet DA, McDonald C, Whitson A, Russ SM, Matsen FA 3rd. (2018) The contribution of the scapula to active shoulder motion and self-assessed function in three hundred and fifty two patients prior to elective shoulder surgery. Int Orthop. https://doi.org/ 10.1007/s00264-018-4027-3

17. Eneqvist T, Nemes S, Bülow E, Mohaddes M, Rolfson O (2018) Can patient-reported outcomes predict re-operations after total hip replacement? Int Orthop 42(2):273-279. https://doi.org/10.1007/ s00264-017-3711-z

18. Sagar KA, Gruber SA (2018) Marijuana matters: reviewing the impact of marijuana on cognition, brain structure and function, \& exploring policy implications and barriers to research. Int Rev Psychiatry 3:1-17. https://doi.org/10.1080/09540261.2018. 1460334

19. Rombach I, Jenkinson C, Gray AM, Murray DW, Rivero-Arias O (2018) Comparison of statistical approaches for analyzing incomplete longitudinal patient-reported outcome data in randomized controlled trials. Patient Relat Outcome Meas 9:197-209. https:// doi.org/10.2147/PROM.S147790

20. Baulot E, Chabernaud D, Grammont PM. (1995) Results of Grammont's inverted prosthesis in omarthritis associated with major cuff destruction. Apropos of 16 cases. Acta Orthop Belg. 61 Suppl 1:112-119. (in French)

21. Caton JH, Ferreira A (2017) Dual-mobility cup: a new French revolution. Int Orthop 41(3):433-437. https://doi.org/10.1007/s00264017-3420-7

22. Ames SE, Cowan JB, Kenter K, Emery S, Halsey D (2017) Burnout in orthopaedic surgeons: a challenge for leaders, learners, and colleagues: AOA critical issues. J Bone Joint Surg Am 99(14):e78. https://doi.org/10.2106/JBJS.16.01215

23. Shubeck SP, Kanters AE, Dimick JB (2018) Surgeon leadership style and risk-adjusted patient outcomes. Surg Endosc. https://doi. org/10.1007/s00464-018-6320-z

24. Jha A (2018) Safdarjung hospital: volume and efficiency but little time for quality. Available at: https://blogs.sph.harvard.edu/ashishjha/2012/10/04/safdarjung-hospital-volume-and-efficiency-butlittle-time-for-quality/ Accessed 07, 20

25. Alvarado O, Trelles M, Tayler-Smith K, Joseph H, Gesline R, Wilna TE, Mohammad Omar MK, Faiz Mohammad NM, Muhima Mastaki J, Chingumwa Buhu R, Caluwaerts A, Dominguez L (2015) Orthopaedic surgery in natural disaster and conflict settings: how can quality care be ensured? Int Orthop 39(10):1901-1908. https://doi.org/10.1007/s00264-015-2781-z

26. Saku SA, Madanat R, Mäkinen TJ (2018) Reasons and risk factors for ninety day re-admission following primary total knee arthroplasty in a high-volume centre. Int Orthop 42(1):95-99. https://doi.org/10.1007/s00264-017-3676-y

27. Chen W, Zhang Y (2018) Prominent and fruitful development of orthopaedic research in China. Int Orthop 42(3):455-459. https:// doi.org/10.1007/s00264-018-3840-z

28. Sun J, Guo Y, Scarlat MM, Lv G, Yang XG, Hu YC (2018) Bibliometric study of the orthopaedic publications from China. Int Orthop 42(3):461-468. https://doi.org/10.1007/s00264-018$3828-8$ 
29. Hernigou P, Daltro G, Hernigou J (2018) Hip osteonecrosis: stem cells for life or behead and arthroplasty? Int Orthop. https://oi.org/ 10.1007/s00264-018-4026-4

30. Kobayashi S, Kubo T, Iwamoto Y, Fukushima W, Sugano N (2018) Nationwide multicenter follow-up cohort study of hip arthroplasties performed for osteonecrosis of the femoral head. Int Orthop. https:// doi.org/10.1007/s00264-018-3980-1

31. Scarlat MM, Mavrogenis AF, Pećina M, Niculescu M (2015) Impact and alternative metrics for medical publishing: our experience with International Orthopaedics. Int Orthop 39(8):1459-1464. https://doi.org/10.1007/s00264-015-2766-y

32. Goldkuhle M, Narayan VM, Weigl A, Dahm P, Skoetz N (2018) A systematic assessment of Cochrane reviews and systematic reviews published in high-impact medical journals related to cancer. BMJ Open 8(3):e020869. https://doi.org/10.1136/bmjopen-2017020869

33. Alves K, Penny N, Kobusingye O, Olupot R, Katz JN, Sabatini CS (2018) Paediatric musculoskeletal disease in Kumi District,
Uganda: a cross-sectional survey. Int Orthop 42(8):1967-1973. https://doi.org/10.1007/s00264-018-3915-x

34. Lisenda L, Mokete L, Mkubwa J, Lukhele M (2016) Inpatient mortality after elective primary total hip and knee joint arthroplasty in Botswana. Int Orthop 40(12):2453-2458

35. Paredes O, Ñuñez R, Klaber I (2018) Successful initial experience with a novel outpatient total hip arthroplasty program in a public health system in Chile. Int Orthop 42(8):1783-1787. https://doi. org/10.1007/s00264-018-3870-6

36. Zheng W, Hu Y, Xin H (2016) Successful implementation of thirty five major orthopaedic procedures under poor conditions after the two thousand and fifteen Nepal earthquake. Int Orthop 40(12): 2469-2477. https://doi.org/10.1007/s00264-016-3284-2

37. van Wijck SF, Oomen AM, van der Heide HJ (2015) Feasibility and barriers of treating clubfeet in four countries. Int Orthop 39(12): 2415-2422. https://doi.org/10.1007/s00264-015-2783-x

38. Waddell JP, Pečina M, Scarlat MM (2017) Imperfection leads to progress. Int Orthop 41(4):669-670. https://doi.org/10.1007/ s00264-017-3440-3 